\title{
Entre espelhos, máscaras, palcos e memórias: o jogo da representação em As horas nuas, de Lygia Fagundes Telles
}

\author{
Among masks, mirrors, stages and memories: \\ the game of representation in Naked hours, by Lygia Fagundes Telles \\ Entre espejos, máscaras, escenarios y memorias: \\ el juego de la representación en Las horas desnudas, de Lygia Fagundes Telles
}

Ana Paula dos Santos Martins

\section{Resumo}

Este artigo busca analisar uma das facetas do jogo de representação no romance As horas nuas (1989), de Lygia Fagundes Telles, a partir da construção da protagonista Rosa Ambrósio. Na recuperação do passado pelo exercício da memória, os papéis femininos por Rosa outrora desempenhados no teatro como atriz misturam-se ao seu repertório pessoal e descortinam a encenação de uma história de sujeição da mulher, suas tentativas de emancipação e a difícil arte de harmonizar a convivência nas esferas pública e privada. Nesse sentido, esses papéis corroboram tanto a relação da protagonista envelhecida com os membros de sua intimidade quanto desvenda a condição plural das mulheres no Brasil da década de 1980.

Palavras-chave: representação, mulher, teatro, memória, criação literária.

\begin{abstract}
This article seeks to investigate the role of representation in the novel Naked hours (1989), by Lygia Fagundes Telles, based on the construction of the protagonist Rosa Ambrósio. By recovering the past through the exercise of memory, the female roles once performed by Rosa as a theatre actress mingle with her own experience and unveil the enactment of a woman's story of submission, her attempts at emancipation and the difficult art of harmonizing her coexistence in the public and private spheres. These female roles portray the relationship of the aged protagonist with those around her and also uncover women's plural condition in Brazil in the 1980s.
\end{abstract}

Keywords: representation, woman, theatre, memory, literary production.

\begin{abstract}
Resumen
Este artículo busca analizar una de las facetas del juego de representación en la novela Las horas desnudas (1989), de la escritora Lygia Fagundes Telles, a partir de la construcción de la protagonista Rosa Ambrosio. En la recuperación del pasado por el ejercicio de la memoria, los papeles femeninos otrora desempeñados por Rosa en el teatro como actriz se mezclan con su repertorio personal y descubren la escenificación de una historia de sujeción de la mujer, sus intentos de emancipación y el difícil arte de armonizar su convivencia en las esferas pública y privada. En ese sentido, esos papeles corroboran la relación de la protagonista con los miembros de su intimidad y desvelan la condición plural de las mujeres en el Brasil de la década de los ochenta.
\end{abstract}

Palabras clave: representación, mujer, teatro, memoria, creación literaria.

Em seu último romance, As horas nuas (1989), Lygia Fagundes Telles constrói a rica subjetividade de Rosa Ambrósio, uma velha atriz em decadência, a partir de um monólogo interior delirante graças ao estado de embriaguez em que ela se encontra. O leitor descobre que ela deseja escrever um livro de memórias, ao mesmo tempo que à sua frente desfilam seus medos e preocupações, como o terror da velhice e da solidão, sua indignação com as

\footnotetext{
* Doutora em letras e professora da Faculdade de Tecnologia de Taquaritinga (FATEC), Taquaritinga, SP, Brasil. (Dorcid.org/00000002-0525-198X. E-mail: anasanmartins@yahoo.com.br
} 
mazelas sociais que assolavam o Brasil de então, os perfis esboçados daqueles que fizeram e fazem parte de sua história de vida. Um emaranhado de lembranças - memória ou invenção? - em que marido, pai, amante, mãe, filha, empregada, analista, ou seja, aqueles que participam de sua experiência doméstica e social, estão "embrulhados" como a própria atriz, como ela gosta de dizer. Ao longo do romance, ela tenta "desembrulhar" para compreender a si própria e sua história, com seus fracassos e vitórias.

O livro organiza-se em torno do jogo da exposição e do ocultamento, seu princípio estruturante. Como romance fragmentado, a começar pelas diferentes perspectivas narrativas - Rosa, Rahul, o gato da protagonista, dotado de pensamento crítico e memória, e um narrador onisciente em terceira pessoa, que focaliza especialmente a personagem Ananta, analista da atriz -, As horas nuas apresenta um enredo aparentemente simples, ao qual não corresponde, no entanto, a complexidade das personagens que "não se esgotam nos traços característicos, mas têm certos poços profundos de onde podem jorrar o desconhecido e o mistério" (Candido, 2007, p. 60). Basicamente, as ações que se desenvolvem no presente referem-se apenas ao fato de Rosa estar embriagada e divagar em seu apartamento, recebendo as raras visitas de Cordélia, sua filha, ou fazendo pouquíssimas sessões de análise com Ananta Medrado, que mora no mesmo prédio que a atriz. Tais ações têm como pano de fundo um momento de profunda descrença no Brasil "redemocratizado", após 21 anos de censura e repressão, que culmina com uma inflação galopante, com a corrupção política sendo desmascarada nas esferas do poder e com a expansão desordenada das grandes cidades, alterando os modos de vida e os códigos de produção de bens e de consumo.

Não é gratuito, portanto, o fato de Lygia ter optado pelo teatro como a grande metáfora da representação em As horas nuas. A escolha da carreira profissional de sua protagonista já torna essa afirmação evidente na superfície do texto - Rosa Ambrósio é uma atriz, aquela cuja função é fundir-se com as personagens que encena e identificar-se com um outro eu (Rosenfeld, 1993, p. 21). Na tentativa de encenar Rosa Ambrósio por si mesma, a atriz revela para o leitor o próprio martírio: "Fiquei sozinha para me executar, sou meu carrasco. Pior do que um estranho porque já me amei, pum! disparo no coração do coração. Caio redondamente morta" (Telles, 1999, p. 48). Como vítima e algoz de si mesma, usa como armas a lembrança e o esquecimento, a fim de compreender sua responsabilidade pela situação "trágica" em que se encontra. Nesse estado limite, a velha atriz precisa empreender incursões ao universo do passado, através da bebida, para preencher o vazio e a falta de interesse por sua vida presente e tentar buscar, nos momentos ociosos, o sentido perdido. Bebe, então, "em homenagem a la busca" (Telles, 1999, p. 12), perpassando necessariamente as fraquezas dos diversos papéis que desempenhara fora do teatro, pela via do remorso: "Atriz medíocre, mãe egoísta, amante infiel e dona-de-casa descuidada" (Telles, 1999, p. 103). Nos momentos em que a vaidade falava mais alto, apregoava que ao teatro dera o melhor de si e que, talvez, tenha representado melhor do que vivera. Na recuperação do passado pelo exercício da memória, os papéis femininos por Rosa outrora desempenhados no teatro como atriz misturam-se ao seu próprio repertório e descortinam a encenação de uma história de sujeição da mulher, suas tentativas de emancipação e a difícil arte de harmonizar a convivência nas esferas pública e privada. Diante do que foi exposto, o objetivo deste artigo é analisar uma das facetas do jogo de representação de As horas nuas, a partir da construção da protagonista Rosa Ambrósio e sua relação com a representação teatral.

Se nos últimos anos a literatura e as artes assistiram à guinada no conceito de representação, ao aparente abandono da referencialidade e às reviravoltas no que tange à noção de experiência, como uma leitura pós-moderna poderia facilmente convencer, por outro lado, uma visão também pós-moderna aponta para o surgimento de novas representações, como as que se desvinculam daquelas tidas como centrais, ocidentais, masculinas, brancas e de classe privilegiada. Basta lembrar a emergência dos movimentos de minorias nas décadas de 1960 e 1970 - gays, lésbicas, mulheres, negros -, um dos mais significativos traços pós-modernos, e dos posicionamentos adotados por teóricos pós-coloniais, no âmbito da cultura, da literatura e das artes. As questões surgidas a partir de então problematizam as relações entre o universal e o particular em 
discussões sobre centro e periferia, nação, diásporas e fim ou permanência das utopias. Diante desse novo "caldo de cultura" é necessário refutar, no entanto, as generalizações e observar com atenção a insistente permanência de vozes que, em meio ao caos, realizam uma literatura de alto valor artístico que, ao fugir de clichês, constitui uma espécie de resistência às tão apregoadas crises contemporâneas da história e da narrativa. Neste artigo, as preocupações teóricas com as maneiras de representar encontram-se ligadas justamente à representação como mediação, calcadas na intertextualidade a partir de referências teatrais e aos diversos papéis sociais vividos pela protagonista com relação às personagens com as quais ela contracena. Numa visão global, pode-se dizer, ainda, que se referem ao projeto literário de Lygia Fagundes Telles como escritora.

A protagonista vive com medo, o qual provém da atávica necessidade de viver com um pé fincado no passado, com tudo o que este representa - a juventude, a família, a fé, o primeiro amor, a vida cotidiana menos atribulada - e o outro na ambição, no desejo insaciável de acumular bens, joias, apartamentos, homens, fama e, assim, projetar-se para o futuro. Esse medo acompanha a tendência de uma cultura para as massas que se inicia, em escala menos avassaladora, com os ditames do cinema hollywoodiano e das revistas femininas de moda e comportamento, passando pela influência da televisão e do desenvolvimento de novas formas de produção e consumo. Desse modo, um traço extraliterário configurador da vida cultural burguesa no Brasil até a década de 1960, mote do projeto de modernização que visava à construção da identidade nacional (Ortiz, 1999), transforma-se, na maneira como afetou as relações familiares, no elemento que acompanha, sob a tensão entre exposição e ocultamento, a dialética do pessoal e do coletivo em Rosa: a necessidade de se reconhecer como membro da elite "civilizada", a fim de justificar sua aproximação com a "modernidade" representada pelas classes sociais abastadas do capitalismo central.

No hiato entre o ontem e o amanhã, a realidade: por um lado, as glórias do teatro, as viagens inesquecíveis, as festas; por outro, a velhice, a solidão, o marido Gregório, a filha Cordélia, a família infeliz relegada a um plano inferior, substituída pela atriz sempre em busca do que não tinha. O presente constantemente adiado: Gregório não era o primeiro amor, procurado em outros homens; Cordélia não tinha ambição, boiava "no rio do supérfluo" e gostava de homens velhos, na maioria pobres, o oposto ansiado pela mãe. A tensão entre passado e ambição, nostalgia e acúmulo, que norteara a vida de Rosa só é abalada quando o corpo começa a dar sinais de seu amadurecimento. Sem ocupação e solitária, tem o tempo necessário para perceber a dissolução de seu núcleo familiar, amoroso e profissional. Todos foram embora: viajaram, morreram ou foram ordenados a se retirar. A juventude passa o bastão à velhice; já não é preciso acumular mais bens: tem fama, dinheiro, propriedades. Para Rosa Ambrósio, não há outra escolha: precisa pisar com os dois pés no presente e encarar o lado negro do espelho, mas tem medo da luz. Embora o sol esteja "sempre em seu rastro", considera-o seu inimigo e, por isso, prefere a escuridão e a solidão do quarto, onde bebe, dorme, chora, monologa ou representa para um público agora restrito, formado apenas pela empregada negra e por seu gato. O estado alterado de percepção, provocado pelo consumo de álcool, permite uma radicalização de seu monólogo, em que a censura ao que pode ou não ser dito é preterida no processo de embriaguez, e a insistência no medo do envelhecimento, no remorso e a repetição recorrente das lembranças é contundente. A constante associação de ideias sugere também que nenhuma lembrança consegue sustentar-se por muito tempo expressa em frases longas, "como se o próprio ritmo discursivo sofresse seus sobressaltos, figurativizando a descontinuidade do trabalho da memória ao resgatar uma matéria difícil de ser digerida" (Silva, 2003, p. 46). A repetição de ideias, frases e sonhos configura-se, portanto, como uma maneira de preservar as "horas felizes" e tentar chegar ao âmago de seu drama pessoal e solucionar o conflito, que se formaliza numa linguagem com o predomínio de frases curtas em que vicejam substantivos capazes de nomear a dor e a falta, em detrimento de uma adjetivação prolixa e de verbos em abundância, já que são poucas as ações da protagonista na narrativa.

Mais uma vez, como em outras narrativas de Telles, o espaço doméstico, metonimicamente representado pelo quarto, tem um valor de redoma, de concha, pois é nele que Rosa se refugia do mundo exterior, preferindo desligar a TV ou deixar de ler jornais, nos quais ela já não figura e que 
trazem para o interior da casa a deterioração da qualidade de vida urbana numa metrópole como São Paulo, característica comum a outras personagens de Lygia pertencentes à alta burguesia.

Assumi minhas curtas verdades, assumi as mentiras compridíssimas, assumi fantasias, sonhos - como sonhei e como sonho ainda! Tudo somado, um longo plano de evasão fragmentado em fugas miúdas. Diárias. Que foram se multiplicando, não leio mais jornais, desliguei a TV com suas desgraças em primeiríssima mão, crimes humanos e desumanos, catástrofes e calamidades naturais e provocadas, ah! um cansaço. Por que ficar sabendo tudo se não posso fazer nada? Posso dar água aos flagelados ressequidos? [...] As tragédias se enredando sem trégua. Não tenho culpa se tomei horror pelo horror conformado. A miséria paciente. Minha mulher, doutor, mais o meu filho com barraco e tudo. Nem o cachorro salvou, sumiu no meio da água, do barro... A Dinamarca envia caixotes de vacinas, o Papa pede a Deus em português. Lá do alto do palanque os políticos filhos-daputa exigem providências, Meus irmãos, meus irmãozinhos! E os irmãozinhos continuam morrendo como moscas, ah! querido Gregório, perdão, mas não suporto mais tanta miséria, merda! Fui batizada, catequizada, conscientizada e tudo isso para ter certeza de que não sou Deus e mesmo que fosse. Estou ciente, e daí? (Telles, 1999, p .10).

Ao longo de As horas nuas, a atriz raramente sai de sua "concha"; quando o faz, é para ir às sessões com sua analista. No interior do quarto, porém, o colchão é substituído por uma trouxa de roupas sujas, a maioria feita de seda, e a cama cede lugar ao chão como espaço privilegiado e metonímico para os devaneios da protagonista. Elemento cuidadosamente utilizado pela escritora, o chão, repleto de sentidos de marginalidade e exclusão, também poderia ser compreendido como limiar, o ponto de contato com a realidade nua e, por isso, estaria em perfeita simbiose com o estágio atual em que se encontra a velha atriz, a situação de outsider: solitária, alcoólatra, idosa e excluída profissionalmente. Rosa é descrita por seu gato como alguém de pés bonitos, os quais circulam descalços pela casa e pelas escadas do prédio onde mora e do qual é majoritariamente proprietária; a ideia de contato dos pés com o chão não se realiza plenamente, no entanto, porque a dureza do piso é substituída pela maciez do carpete que o recobre, cobertura atapetada aplicada aos referidos ambientes por solicitação da protagonista - símbolo evidente do medo da nudez, do verdadeiro contato com a frieza do chão, estendida à crueza do conflito de ordem pessoal/social por ela vivido. Embora tenha tentado fugir dessa realidade, a "resistência acolchoada" desse "espaço em camadas" em que se constitui sua concha-quarto-apartamento-prédio não impede, portanto, a reprodução da cidade em pequena escala, com seus múltiplos espaços sociais conflituosos reiterados nas relações familiares, estratégia comum nas narrativas escritas por mulheres no Brasil (Dalcastagnè, 2003, p. 47), que se dá na retomada de lembranças do passado. Desse modo, família e passado ganham importância crucial em As horas nuas, assim como nos romances anteriores da escritora e em outras narrativas de autoria feminina. Semelhante ao processo de análise, ao qual a atriz se submete sem sucesso, a possibilidade de cura do seu estado atual de autorrejeição está, portanto, no exercício da palavra que, ao longo do romance, assemelha-se a uma espécie de ensaio do livro de memórias que pretende escrever.

A atriz sente-se como única responsável por sua degradação e, por isso, tem dificuldade de reconhecer sua própria face, uma vez que foram inúmeras as máscaras sociais por ela usadas, cujas características são as mesmas das dos membros de sua classe econômica e cultural, principalmente no que se refere à inadequação entre as ações praticadas e o discurso moralista pregado. A essência do trágico, cujo espírito mantém-se como base do drama moderno, residiria, pois, na tensão entre a peripécia e a ironia dramática. Em Rosa, no entanto, o destino é reconhecido como as condições que atuam principalmente no novo papel da mulher e na nova configuração familiar, com a concomitância de problemas de ordem psicológica e social, o que revela não apenas o elemento trágico na protagonista, mas sobretudo, o dramático. A consequência dessa tensão em Rosa recai na acepção de trágico de Northrop Frye (1973, p. 4142), como aspecto geral do enredo, que pode ser interpretada como seu isolamento da sociedade à qual pertence. Nesse sentido último, é possível compreender que, embora o projeto profissional tenha sido bem sucedido até chegar à velhice, é na nova condição de mulher idosa 
que a atriz se frustra com a inversão de planos e com o poder da lógica de aparências da sociedade em que vive, cujo modelo de família também entra em franca decadência.

Há um traço dramático em As horas nuas, utilizado aqui na acepção adjetiva apontada por Anatol Rosenfeld, que extrapola a questão da representação no âmbito meramente temático. Esse traço se configura na própria estrutura da obra, marcadamente nas personagens que narram em primeira pessoa. Assim como na dramática pura, ao longo do romance em questão existe uma situação existencial com o objetivo de estimular a mudança de status quo das personagens mencionadas, a saber, a tensão entre expor e ocultar memória e realidade. A encenação, de origem dramática ou cinematográfica, visa a um futuro desconhecido, que brota do desenvolvimento de ações no presente, embora, no teatro, as dramatis personæ possam evocar situações e eventos anteriores ao momento da enunciação. Diferentemente de uma peça teatral, no entanto, no romance e no cinema há a possibilidade de se voltar ao passado, com o recurso do flashback, o que denuncia a ação de um narrador ou de alguém por trás da câmera, manipulando a narrativa, escolhendo o que deve ser dito ou mostrado ao leitor, ao público. No caso de As horas nuas, por trás de Rosa Ambrósio, de Rahul ou da onisciência seletiva que apresenta a personagem Ananta, oculta-se o autor implícito que, a partir desses diferentes pontos de vista, recorta e manipula o que deve ficar claro e o que deve permanecer obscuro na economia do livro. Como a personagem Rosa está profundamente envolvida nas situações recordadas, não há a distância que produz a visão centralizada em um alguém que narra, mas exigem-se "adaptações estéticas capazes de incorporar o estado de fluxo e insegurança dentro da própria estrutura da obra" (Rosenfeld, 1996, p. 86). Essas adaptações traduzem-se mesmo na técnica utilizada - monólogo e monólogo interior - e no cruzamento da exploração da vivência subjetiva da atriz com a de seu gato e da analista, o que se dá num jogo de espelhamento que revela a precariedade das perspectivas no enfoque do real e que se constitui, no caso de Rahul, em uma espécie de imagem refletida da atriz e, em seu avesso, no que se refere a Ananta. Assim, a possibilidade de narrar torna-se remota, pois o narrador revela-se como uma instância dissolvida no monólogo interior/fluxo de consciência das personagens, e a distância entre matéria narrada e leitor é reduzida se comparada à distância mantida pelo romance tradicional.

O discurso de Rosa também é marcado pela referência ao teatro, em que o uso das expressões "entrar" e "sair de cena" são constantes. A atriz ressalta que tem uma queda pelo estilo dramático, o que, segundo a personagem, é herança de sua mãe. A ambiguidade desse estilo remete diretamente ao duplo sentido do termo, como comportamento ligado à emoção e como as peças que encenam conflitos da vida real. Por essa razão, a tragédia e o drama são as formas da dramaticidade à qual a velha atriz dedicou toda sua carreira. A força das personagens das peças por ela encenadas, como Hamlet, Vestido de noiva e Quem tem medo de Virginia Woolf? (Who's afraid of Virginia Woolf?), ou apenas mencionadas, como Macbeth, Otelo, À margem da vida (The glass menagerie), Fausto ou Longa jornada noite adentro (Long day's journey into the night), ${ }^{\prime}$ reside justamente no fato de que todas elas carregam traços demasiadamente humanos, em que as tensões entre aparência e realidade, entre bem e mal, são parte mesmo de seu caráter, fugindo do maniqueísmo, característica comum às personagens de Telles em sua vasta obra.

Em todas as personagens encenadas profissionalmente ou apenas mencionadas por Rosa, pertencentes, em sua grande maioria, a uma classe social privilegiada - Ofélia, Lady Macbeth, Margarida, Alaíde, Martha, Amanda, Margueritte, Princesa Kosmonópolis -, a loucura, o desencontro, a incomunicabilidade, o abandono, o peso do passado, o apagamento das fronteiras entre ilusão e realidade decorrem dos dilemas do relacionamento conjugal e/ou da estrutura familiar. Estes são configurados pela manutenção ou desagregação da ordem patriarcal, mantida a fidelidade aos contextos em que aquelas peças foram escritas e publicadas, dos quais a sede de poder, a vingança, a inveja, o ciúme, a traição e a manutenção das aparências são fruto de uma instituição familiar tida como repressora, ou seja, suas consequências mais aparentes. A única

\footnotetext{
1 Embora tais peças teatrais tenham um sentido de denúncia e/ou contestação da ordem vigente, que no caso dos dramas norteamericanos está ligado ao desmascaramento dos efeitos do "sonho americano" sobre a vida das personagens, esse sentido não será explorado aqui devido à maneira como Rosa recupera os textos encenados - como seus espelhos -, justamente por desprovê-los de contextualização, em perfeita sintonia com sua própria condição de burguesa alienada.
} 
exceção é Arlequim polido pelo amor (Arlequin poli par l'amour), de Pierre de Marivaux, uma comédia francesa do século XVIII, escrita nos moldes da commedia dell'arte italiana. ${ }^{2}$

A técnica empregada por Lygia na apresentação de Rosa, Rahul e Ananta, semelhante à de Virginia Woolf, garante a interposição de planos variados, graças ao uso de procedimentos que aprofundam ou radicalizam a análise mental, pois parte de um acontecimento exterior insignificante, para dizer com Auerbach, capaz de liberar "idéias e cadeias de idéias, que abandonam o seu presente para se movimentarem livremente nas profundidades temporais" (Auerbach, 1994, p. 487). Por isso, a simples referência ao sucesso com a peça Vestido de noiva, ${ }^{3}$ de Nelson Rodrigues, ocorre pela associação com os "tempos de muita roupa" (Telles, 1999, p. 16) em oposição ao momento vivido e criticado por Rosa no presente da narrativa, a década de 1980, em que os corpos nus, belos e perfeitos explodiram na televisão e na mídia em geral -, a partir da lembrança da quantidade de botões do vestido que Rosa usara no próprio casamento, os quais Gregório nunca terminava de desabotoar. Esta é a única peça nacional citada, conhecida por ter renovado a dramaturgia brasileira moderna, por apresentar a fluidez da narrativa em diversas dimensões de tempo e espaço, diferentemente do que a plateia brasileira "estava acostumada a seguir, ao menos pela duração de um ato, uma única ação, evoluindo linearmente no tempo e ocorrendo numa localização também única e específica" (Nunes, 2004, p. 16).

No que concerne às técnicas de representação, o paralelismo entre o drama de Alaíde, protagonista da tragédia de Rodrigues, e o de Rosa evidencia-se na já citada interposição de planos espaço-temporais variados como os da realidade, da memória e da alucinação. No caso de Rosa, essa interposição é oriunda dos devaneios provocados pelo álcool, ao passo que a subconsciência de Alaíde é trazida à tona pelo estado de choque em que se encontrava no hospital para onde foi levada e operada. Lygia Fagundes Telles introduz o plano da realidade em As horas nuas à semelhança de Rodrigues, durante os devaneios de Rosa: em Vestido de noiva, "a realidade tem o papel simples de situar os acontecimentos, estabelecendo-lhes cronologia e relação" (Magaldi, 1998, p. 24), como o barulho das buzinas e dos automóveis, a tentativa dos médicos de salvar Alaíde ou as conversas entre jornalistas, os quais pedem e transmitem informações à redação dos jornais sobre a jovem da alta sociedade carioca atropelada, assim como em As horas nuas, quando a entrada ou a tosse de Dionísia, um de seus espelhos verdadeiros, tem a função de remeter Rosa ao presente e à realidade, interrompendo temporariamente o fluxo de suas lembranças.

Segundo Nunes (2004, p. 17), "as distorções da narrativa criadas pelas elucubrações subconscientes de Alaíde são, na realidade, um artifício dramático, que vai sendo gradualmente desmascarado, até que finalmente a realidade impõe-se por completo". Em ambos os casos, em Alaíde e em Rosa, os fatos passados, a matéria mais recôndita guardada no subconsciente das protagonistas, vão emergindo a partir do exercício da rememoração em meio a um caos em que se misturam imaginação e realidade - sonhos, desejos, fantasias, romantismo, doces e amargas lembranças. A recordação do casamento, da traição do marido com uma mulher da mesma

\footnotetext{
${ }^{2}$ De todas as peças mencionadas por Rosa, Who's afraid of Virginia Woolf? e Arlequin Poli par l'amour são as mais significativas em termos de mediação no tocante à construção das personagens de Gregório e Diogo e aos papéis sociais de esposa e amante decorrentes desse jogo de representação no que concerne à protagonista. Por essa razão, constituem matéria a ser tratada em outro artigo.

${ }^{3}$ A peça, de 1943, retrata, em três diferentes planos - o da alucinação, o da realidade e o da memória -, a classe média carioca da década de 1940, a partir da personagem Alaíde, jovem rica que é atropelada numa rua do Rio de Janeiro. No plano da realidade, tem-se a movimentação dos repórteres que buscam notícias sobre o estado da jovem, a conversa de Pedro, marido de Alaíde, com os médicos que tentam salvá-la, a morte da protagonista, o velório, o luto dos parentes e o casamento de Pedro com Lúcia, irmã da jovem morta. Os planos da alucinação e da memória confundem-se num misto de projeções em que Alaíde procura por uma prostituta, Madame Clessi, que havia residido na casa em que então moravam seus pais e que fora assassinada no início do século XX, por seu namorado, um rapaz de 17 anos. Alaíde encontra na figura de Clessi a base para a reconstrução de fatos passados e da revelação de seus desejos, a partir de sonhos como o assassinato de Pedro, o marido traidor. Recorda-se, com a ajuda da prostituta, cujo diário Alaíde havia encontrado no porão da casa de seus pais, que havia conquistado todos os namorados de Lúcia, sua irmã, inclusive o último, Pedro, com o qual se casara. Em seu delírio misturado às lembranças esgarçadas, demonstra sua frustração pela vida de casada, ao mesmo tempo em que se sente ameaçada de morte por Pedro e Lúcia. Alaíde tenta se lembrar do dia de seu casamento, da discussão com sua irmã e recorda que, dias antes do acidente, desconfia que será assassinada por Lúcia e Pedro. Enquanto o fio de vida se esvai, Alaíde tenta reconstruir em sua mente os acontecimentos passados, misturando-os à satisfação dos desejos mais recônditos. Por fim, a jovem rica e a cafetina assistem ao velório e enterro de Clessi e, com a morte de Alaíde, Lúcia casa-se com Pedro, mesmo tendo em sua mente a imagem da irmã no dia de seu casamento, vestida de noiva.
} 
família (em Vestido de noiva, a própria irmã de Alaíde e, em As horas nuas, uma prima de Rosa), da ideia de competição existente entre as mulheres, da necessidade de novas experiências para a figura feminina, que se sente encarcerada nos moldes, nos papéis predeterminados para a antiga mulher, são os elos que unem essas personagens. O resultado, porém, tem nuances distintas: se em Vestido de noiva a instituição familiar é alvejada de modo violento pelo autor a partir da decadência moral da classe social aí retratada - a burguesia carioca -, em As horas nuas, a vida familiar burguesa é fonte de dor, mas sem a caracterização quase grotesca; nela, Rosa parece apostar suas últimas fichas por desejar reconstruir sua relação com Diogo.

A referência teatral mais importante para Rosa consiste, no entanto, na tragédia de William Shakespeare, Hamlet, seu primeiro grande papel. A rememoração da personagem Ofélia, assim como todas as outras que encenara, surge das divagações da protagonista, que passa grande parte do tempo, como vimos, desejando voltar a ser uma atriz ativa, a responder à vida novamente "com êxtase e entusiasmo", para a qual o retorno de Diogo torna-se condição sine qua non, seguida da publicação de seu livro de memórias. Ao recordar o fato de sua filha manter relacionamentos amorosos com homens mais velhos, por exemplo, Rosa estabelece Gregório, já morto, como interlocutor mudo para quem menciona o comportamento de Cordélia com desprezo, atitude que seu marido condenava, pois achava que a liberdade era fundamental para que cada qual fizesse suas próprias escolhas. A opinião de Gregório sobre aquele assunto fica sugerida na frase retirada da peça mencionada: "Sê afável mas não vulgar! ele pediu" (Telles, 1999, p. 46). Em seguida, a atriz instala sua própria dúvida no leitor: "Hamlet ou o tio?", sem saber se essa fora a frase dita realmente pelo marido, pela personagem de Hamlet ou de Polônio, o conselheiro que vive na corte da Dinamarca e é pai de Ofélia, personagem vivida por Rosa no teatro. Como se vê nessa passagem, a velha atriz também questiona os limites entre memória e ficção.

No fluxo contínuo da memória, ela recorda a longa cantoria de Ofélia, cuja extensão compara à loucura e à velhice ("loucura e velhice têm de ser compridíssimas"), e também de trechos de sua interpretação no palco, como o momento em que descia a escadaria cantando, coroada de flores, e do comentário feito pelo crítico de barbicha loura, que quis dormir com a atriz ("haja saco!"), de que ninguém resistia ao canto de Rosa nesse papel, semelhante a um "doce sussurrar de águas puras". Nesse mesmo fluxo, a protagonista acredita que representou bem o papel de Ofélia,

mas quando saí do palco a dor continuou enterrada no meu peito até o cabo. As personagens insistindo, uma noite cheguei a me assustar, era Hamlet e não Diogo que me apareceu com aquele queixo duro, eu querendo o Arlequim de coração contente e me vem um Pierrô sinistro, as narinas abertas intuindo podridões. Mas seu rancor era raro e breve (Telles, 1999, p. 47).

Na peça de Shakespeare, a dor e a loucura de Ofélia são resultantes da morte de seu pai, da partida do irmão e também do afastamento do príncipe Hamlet, que envolve a moça inocente em seu plano de vingança pela morte do rei Hamlet. Sem figura masculina protetora, do pai, do irmão ou de um marido, a jovem enlouquece e morre afogada. Ao ter de escolher entre a obediência ao pai - afastar-se do amado, futuro rei - e o amor de Hamlet, Ofélia fica com a primeira opção. Na conversa entre ela e Hamlet, forjada por Polônio e pelo rei Claudius, a quem o príncipe deseja destruir por ter assassinado o seu pai, o jovem encena toda sua suposta loucura diante de Ofélia, acusando-a, inclusive, de desonestidade, pois sabia que aqueles dois a tudo ouviam, às escondidas, a fim de comprovarem que o estado de insanidade do príncipe originava-se também na desilusão amorosa provocada por Ofélia, sem que soubessem que se tratava de uma estratégia de vingança do herdeiro do trono contra seu antagonista.

Ofélia é, segundo Frye, a representação da figura do suplicante, comum nas tragédias, cuja imagem é a do completo abandono e desamparo. "Sua base é a exclusão de um indivíduo de um grupo, por isso ataca o medo mais profundo que temos em nós" (Frye, 1973, p. 214); as figuras mais comuns de suplicante são, além de crianças, mulheres ameaçadas de morte ou violação, bem como de personagens que se encontram na "posição estruturalmente trágica de ter[em] perdido um lugar de grandeza" (Frye, 1973, p. 214), como ocorre com Ofélia ao ser incluída no plano vingativo de Hamlet. Alguns críticos como A. C. Bradley (2009, p. 118) concordam com a constatação de que da "natureza infantil e da inexperiência de Ofélia tudo 
depende" e que embora não amasse Hamlet profundamente, deu-lhe todo o amor de que era capaz. Nesse sentido, Rosa sente e revive no conflito de Ofélia, figura feminina ligada à representação da protagonista de As horas nuas como muito jovem e inexperiente, a dor pela perda do pai, a morte do primo por quem fora apaixonada e a decepção com o marido Gregório. Embora afirme que se casou virgem, comportamento preconizado pela Igreja e pela moral burguesa, a atriz também não amava o esposo profundamente como Ofélia e, por isso, passou a pautar sua vida amorosa pela busca de homens que a satisfizessem ou a vingassem depois de descobrir a tola traição do marido, meses depois de seu casamento. No entanto, o sentimento de culpa pelas traições que também fizera a Gregório, juntamente com a chegada da velhice, seus efeitos sobre o corpo e o afastamento progressivo dos palcos levam Rosa ao limiar da loucura com a embriaguez, e permitem seus questionamentos mais redundantes, os quais dizem respeito aos homens de sua vida que foram embora: os amores perdidos (Miguel, Gregório e Diogo) e o pai que saíra para comprar cigarros quando ela ainda era uma adolescente e nunca mais voltara. Em sua vida presente, em que esses "esquecidos [voltam] com tamanha força, ululando nos sonhos e fora, uma conspiração" (Telles, 1999, p. 47), sejam eles o pai, o primeiro amor, o marido, o amante, nos quais se incluem também o crítico de teatro, Rosa, na verdade, perde as referências entre realidade e imaginação, vestindo-se mais uma vez de personas, às quais, no entanto, não consegue corresponder no tocante aos papéis sociais que lhe são atribuídos: os de filha, esposa e mãe tradicionais. Ao levar para o ambiente doméstico o drama vivido no palco, dialoga, na vida real, com a problemática do relacionamento de sua personagem, chegando a colocar a máscara também no amante anos depois desta encenação, o qual, num momento de rancor, apresentava um comportamento semelhante ao de Hamlet, pressentindo alguma mentira da atriz no ar - a figura da podridão, da corrupção da tragédia de Shakespeare - o que duraria, no entanto, poucos instantes. $O$ processo de assumir como sua a dor da personagem acaba fundindo-a em Rosa, que toma dela características que passam a fazer parte de seu repertório, o que explica a projeção em Ofélia das insatisfações e desejos pessoais de Rosa; melhor dizendo: no drama vivido no palco, ela vê seus próprios conflitos espelhados, mas não consegue mais separar invenção de memória, pois a máscara está perfeitamente aderida.

Segundo Rahul, o gato, Rosa contara que, quando jovem, fora convidada para fazer o papel de Margarida, da tragédia Fausto, do escritor alemão Johann Wolfgang von Goethe. A atriz participou de alguns ensaios da peça, mas acabou desistindo da atuação; atribuiu à incompetência dos atores, do diretor e da cenógrafa o motivo dessa desistência. Em tom zombeteiro, após uma discussão com Diogo, afirmou:

Há de ver que quem tinha razão era aquele diretor implicante, foi meu segundo papel. Me lembro que fazia tantas caras encarnando a pobre Margarida que por mim o doutor Fausto não venderia ao Diabo nem o botão do colete, quanto mais a alma. Hem?!... (Telles, 1999, p. 30).

A verdadeira razão para essa desistência, no entanto, deve-se, mais uma vez, ao paralelismo que a protagonista estabelece entre sua tragédia pessoal e a da personagem a ser encenada no palco. Assim como a atriz antes do casamento, Margarida era jovem, religiosa, virgem e pobre; vivendo numa situação de escassez de recursos, encanta-se com as joias recebidas pelo galante Fausto e sucumbe aos seus desejos sexuais. É uma personagem romântica e pura, aparentemente corrompida por ser responsável, indiretamente, pela morte da mãe e do irmão. Abandonada por Fausto e com a família destruída, desiste da maternidade, afogando o recém-nascido, fruto de sua relação com o amado doutor e, por esse crime, é presa e condenada à morte. Depois de uma visão da pobre moça encarcerada, Fausto transporta-se para dentro da cela de Margarida e sugere-lhe que fuja juntamente com ele; a jovem, porém, permanece firme no propósito de pagar por sua dívida. Na morte, ela obtém a redenção: é salva e conduzida ao Paraíso, frustrando os planos de Mefistófeles.

É sintomático o fato de que Margarida tenha sido o segundo papel de Rosa no teatro, após Ofélia; no entanto, mais sintomática ainda é sua ligação com a perda sofrida por Rosa com a aceitação do papel de Ofélia em troca da entrega sexual ao diretor de teatro. A personagem Margarida encarna, portanto, a transição da inocência à experiência para a protagonista de $A s$ 
horas nuas. Rosa sente-se incapaz de representar seu segundo papel no teatro e dele desiste porque foi corrompida, mas se sente indigna de redenção, pois, ao contrário de Margarida, continuou a atender prontamente, como Fausto, aos desígnios de Mefistófeles. Assim, a protagonista de As horas nuas assume atributos típicos do caráter masculino da cultura, do desejo de domínio da natureza por meio da razão, isto é, sua completa inserção no mundo dos homens: a busca do dinheiro, da juventude a qualquer preço, como parte do processo de autoconhecimento. A partir de então, os papéis encenados no palco não coincidem mais com personagens românticas e angelicais como Ofélia e Margarida, mas carregam os traços 'demoníacos', autodestrutivos, no comportamento de Martha, de Quem tem medo de Virginia Woolf?, ou menos idealizados como os de Amanda, de À margem da vida e de Alexandra Del Lago em Doce Pássaro da Juventude, como veremos em seguida.

As tragédias e dramas pessoais de Rosa Ambrósio, portanto, nasceram das escolhas que essa personagem de espírito dramático foi levada a realizar em consonância com os ditames sociais, voltadas sempre para a manutenção das aparências, que, por sua vez, era reforçada pela crença de que, em sua beleza física, a atriz poderia encontrar a própria fonte da juventude e da felicidade. Quando chega à "idade da madureza", é interessante notar que Rosa tenta desesperadamente estabelecer interlocutores em seu monólogo quase ininterrupto, o que corresponde ao esforço de transformar em diálogo o fluir solitário de sua consciência. A estrutura dialógica, característica do teatro, é uma forma de apresentar os conflitos a partir da ação dos atores em cena, com suas réplicas, sem interferência de um narrador. Seu uso, por Rosa, caracteriza-se como mais uma marca arraigada da atividade teatral na personagem e tem um duplo sentido no romance: vencer a solidão e tentar encontrar no outro a resposta para seus próprios conflitos pessoais. Dentre seus interlocutores preferidos, encontram-se Gregório, a mãe, o pai, Miguel - em suma, aqueles a quem ela não tem mais. Cordélia e Dionísia não entram completamente nesse jogo, pois a atriz ainda não as perdeu, mas Ananta será facilmente substituída por um gravador, que se assemelha, em seu silêncio e impossibilidade de réplica, ao comportamento da analista. No entanto, como Rosa reconhece, aqueles mortos não ajudam. Os que realmente poderiam colaborar foram eliminados de seus guardados, tiveram suas fotografias rasgadas, excluídos como testemunhas capazes de apontar o processo de mentiras e degenerações a que se entregou. Seu inevitável reencontro com esses mortos dar-se-á na Praça da República, onde acontece uma espécie de renascimento da protagonista, ou, como Aristóteles preconiza na Poética, quando se dá o processo de reconhecimento, aspecto fundamental do mythos na Tragédia, da imitação de ações, o que não implica cópia mas recriação do real, em conformidade com o caráter e o pensamento das personagens.

No episódio em que descobre que Diogo havia telefonado, Rosa dirige-se a uma clínica de desintoxicação e, ao entrar no consultório, nota a semelhança física entre o médico e o exsecretário/amante, mas percebe que aquele não poderia ajudá-la. Para desvencilhar-se do local, usa mais de suas mentiras, como a desculpa de que marcara aquela consulta no mesmo horário do ensaio da peça À margem da vida (The Glass Menagerie), do estadunidense Tennessee Williams, em que atuaria como Amanda Wingfield, papel que, segundo Rosa, 'sempre' quis fazer. Tratase de uma memory play, cuja ação é delineada a partir das memórias do narrador Tom Wingfield, que organiza os fragmentos dispersos, e tem por cenário o apartamento da família Wingfield, na St. Louis de 1937, durante a Depressão norte-americana. Tom é o responsável pelo sustento da casa onde mora com sua mãe, a sonhadora Amanda, e sua irmã, Laura. Todas as personagens têm uma experiência de abandono e fragilidade, o que se dá inicialmente pelo fato do Sr. Wingfield ter deixado a família há anos e que tem na metáfora dos bibelôs de cristal (the glass menagerie) que Laura colecionava, sua expressão. Tom desejava ser um poeta e fugir do ambiente doméstico no qual se sentia sufocado, impedido de alçar voos mais altos, sob o peso da responsabilidade para com a família. Sua irmã Laura é manca e apresenta um complexo de inferioridade que a impede de superar a dificuldade de se relacionar com o mundo exterior. Diante da percepção do desejo do filho de também ir embora, Amanda impõe a condição de que, antes de partir, Tom precisaria encontrar um pretendente para Laura, uma espécie de substituto para o posto de ganha-pão da família. O que Amanda tenta fazer é garantir seu 
futuro e o da filha às custas de uma figura masculina, tentando repetir o mesmo esquema tradicional a que se submeteu. Essa tentativa é frustrada, pois o pretendente trazido por Tom, um antigo amor de sua irmã, estava noivo, o que direciona Laura para uma situação definitiva de incapacidade para a vida. Depois de uma forte discussão com Amanda, Tom deixa a família, mas a lembrança de Laura é acompanhada de grande remorso, o que faz concluir que, mesmo tendo ido embora, ele não conseguiu deixar sua família - a memória é a inquiridora de todas as personagens, assim como ela também o é para Rosa Ambrósio.

Utilizando o artifício da representação como invenção, no sentido de mentira, a atriz confunde uma vez mais os limites com a realidade tal como Amanda, mas a referência a esta peça assume novas conotações. A Sra. Wingfield, como Rosa, passa de uma mocidade feliz a uma velhice solitária: quando jovem, não lhe faltaram pretendentes, festas e participação ativa nas rodas sociais; no presente, resta-lhe que a memória possa "[...] embelezar o passado na recriação mítica de um tempo perfeito, para oferecer-lhe agasalho contra a rudeza atual [...]" (Magaldi, 1999, p. 354). Para ambas as personagens, a figura masculina se faz necessária na projeção de futuro, mas com ênfases diferentes: se, para Amanda, tal figura teria a função de provedor da casa, para Rosa a simples companhia de Diogo deveria garantir sua luta contra a solidão, ao passo que a função de mantenedora das necessidades financeiras do amado, papel tradicionalmente atribuído ao homem da casa, ficaria a cargo da velha atriz. Por outro lado, Amanda seria o prenúncio da aceitação do papel de uma mulher de meia-idade, cujas características foram incorporadas pela atriz: fantasiosa, sonhadora e impetuosa. O título da peça em português, À margem da vida, oculta do médico, revela ao leitor, no entanto, a partir das técnicas de representação utilizadas pela autora, a maneira como Rosa compreende sua atual condição de outsider, de quem realmente está à margem, vítima de preconceitos também enraizados na própria atriz, no que tange à velhice e à passagem do tempo.

$\mathrm{Na}$ cena em que enfim consegue sair da clínica, Rosa passa por muita gente nas calçadas até encontrar um táxi, cujo motorista está impregnado pela implacável dureza e pela impaciência da cidade. A atriz percebe que esquecera, no consultório, os óculos escuros, companheiros de longa data, com os quais se protegia da luz, do sol, considerado seu inimigo; esse esquecimento configurar-se-á como a metáfora catalisadora da iminente transformação da protagonista. A partir desse momento, Rosa é obrigada a encarar o sol e a realidade da cidade onde mora, sem artifícios que pudessem impedi-la de reconhecer sua complexidade, e sofre um primeiro impacto: ela pede ao motorista que siga ladeira abaixo. Diante da impaciência e da grosseria do taxista, que precisa saber o destino certo da ocupante, Rosa pede que ele entre na Praça da República; sente-se diminuída, novamente, em meio ao desconforto do veículo e do trânsito caótico de São Paulo e, numa atitude de autodefesa, apela para mais uma de suas representações: atribui a culpa de seu estado de atordoamento ao fato de ter acabado de voltar de um hospital, onde uma pessoa que ela amava muito estava morrendo. O motorista afirma que, mesmo pagando, não é possível que Rosa passeie por aquele trecho congestionado e sugere que ela desça na esquina mais próxima. Ao notar que o motorista se comoveu, pois desejou que seu enfermo melhorasse, Rosa sente seus olhos dançarem "nas lágrimas do doente que não existe" e observa, por si mesma, que foi "além da representação" (Telles, 1999, p. 171). No momento da saída do táxi, titubeia: "é melhor não entrar" na praça, precisa "ficar no casulo", mas "até quando?" (Telles, 1999, p. 171). No interior de seu "mundo-para-si", a atriz, assim como outras protagonistas de Telles, também apresenta uma imensa dificuldade de dar o passo em direção à saída diante das situações dramáticas a serem enfrentadas, dificuldade que, como vimos, está calcada no medo. Na ficção de Lygia, a saída do ambiente doméstico é indício de um iminente processo de renascimento ou transformação, que vem acompanhado sempre pelo abandono da escuridão do quarto em favor da claridade do dia, que metaforicamente representa a luz, a resposta para os seus questionamentos. Esse deslocamento da atriz do edifício onde mora em direção à rua, semelhante à saída de Raíza, de Verão no Aquário (1963), segundo romance da escritora, rumo à igreja no final do romance, é um indicador textual de uma primeira abertura da concha, uma espécie de enfrentamento dos fatos depois de anos de autorreclusão em seu apartamento - uma possibilidade de experiência. Mabel Knust Pedra faz 
uma observação complementar, no estudo que realiza sobre Ciranda de pedra e alguns contos de Lygia Fagundes Telles, de como características do tempo meteorológico aliam-se ao tempo psicológico no referido romance, "no desvendamento de questões conflituosas, e termos relacionados aos eventos climáticos se tornam índices de acontecimentos que vão trazer importantes transformações" (Pedra, 2005, p. 28-29), normalmente situações que envolvem grande tensão psicológica. Com a solução ou o alívio da tensão, "desfaz-se ou ameniza-se o elemento natural que emoldurou o momento de aguda interioridade" (Pedra, 2005, p. 29), como também acontece em As horas nuas.

Rosa vê a praça da sua infância, onde costumava ir com o pai e assusta-se com a degradação da cidade e da própria civilidade, explícitas na miséria transbordante que ocupa a antiga praça de suas boas lembranças, tomada por cabeludos fazedores de pulseiras e camelôs com suas bancas repletas de doces expostos ao vento - os verdadeiros outsiders. Diante dos bustos depredados, de "homens que ninguém mais conhece", Rosa sente na pele a perda do sentido de história, de passado e da própria memória, que acompanha a cidade, representada pela praça de antigos gramados londrinos. Ao não reconhecer o antigo espaço utópico, ligado à infância e à inocência, Rosa parece se dar conta do lado negro da modernização ocorrida, que induziu a um processo de urbanização/exclusão sem precedentes e que gerou uma megalópole marcada pela violência, "pela desestabilização de valores, pela lógica da exclusão" (Gomes, 1999), num período que se estende do final dos anos 1940 até o final da década de 1980, e que coincide com a passagem de sua infância à velhice. Percebe, então, aquele espaço como conhecido e desconhecido, símbolo das transformações rápidas e profundas que se operaram na sua cidade, como a evidente perda de elos comunitários, que passou a abrigar todas as classes sociais, desde a alta burguesia, que é a da protagonista, passando pela operária e chegando aos mascates, aos sem carteira assinada, aos sem teto. A cidade é vista pela personagem como uma:

[...] imensa arena de discursos gastos e dispersos, lugar da inscrição e rasura dos signos que desafia o olhar do habitante, que busca ler a ilegível linguagem da cidade dimensionada na metrópole que perde o seu métron: a forma das cidades sem forma, em que a desmedida do espaço afeta suas relações com o humano. A cidade, assim, vai-se qualificando como a Babel que prospera com a perda das conexões e a falta de referência aos valores do passado. É palco para a atrofia progressiva da experiência ligada à tradição, à memória válida para toda a comunidade, substituída pela vivência do choque, ligada à esfera do individual (Gomes, 1999, p. 26).

Mais do que isso: com esse recurso, Lygia situa Rosa num espaço que se consolida como representação metonímica de uma São Paulo que abarcou em um período de 40 anos uma "sociedade em movimento" (Novais e Mello, 1998, p. 585), em que a protagonista é mais uma na multidão, com seus próprios problemas e sente que está "livre do flagelo de sair da moda, de ficar um dia como esses pobrezinhos que já saíram faz tempo e continuam em exposição [...]" (Telles, 1999, p. 172). Assim, "o lamento da protagonista se deve não só à perda, mas também à percepção da enorme distância entre tempo vivido e presente, algo que expõe tanto perdas exteriores (sujeira, miséria, violência) quanto interiores (envelhecimento, decadência, esquecimento)" (Lucena, 2008, p. 126). A atriz garante, repentinamente, que perdera o medo e a ambição, pois se reencontra com o símbolo de seu "paraíso perdido" (Lucena, 2008, p. 126), a praça, local frequentado na infância em que se sentia feliz e segura. Esse reencontro, então, corrobora a passagem para seu suposto renascimento interior, tal como um rito de passagem:

O retrato que tirei com meu pai onde foi parar? Rasguei tanta papelada, cartas e documentos rotos dentro dos plásticos rotos. As testemunhas picadas em pedaços tão miúdos - adiantou? Aos poucos elas vão se refazendo e me seguindo passo a passo na procissão lamurienta, eu sangrando na frente com a cruz da memória. Resisto, empaco, quero fugir e Eleonora me segura pelo braço, está atenta (Telles, 1999, p. 173).

Nesse fragmento, tem início o processo de revelação da origem do medo da atriz por meio de um procedimento narrativo em que a autora implícita instaura as duas primas de Rosa, Eleonora e Zelinda, como as testemunhas que se refazem no fluxo de lembranças e refazem em retrospectiva o passado obscuro da protagonista. Trata-se, desta vez, de um recurso ligado à 
dificuldade de comunicação e à culpa da atriz, que, ao dar uma voz imaginária às duas personagens já mortas, permite que ambas apontem a verdade que, enfim, vem à tona, pois Rosa não é capaz de dizê-la por si mesma, embora toda essa matéria seja constituída de lembranças, dentro de seu fluxo de consciência. Desse modo, a protagonista, desdobrada em duas narradoras-testemunhas imaginárias, muda o ângulo de visão, em que a narração tem como objeto narrado sua verdade mais recôndita, em que Rosa sente ainda mais o pesado fardo que carrega, pois se coloca na posição de quem observa e é observada, de quem aponta e é apontada. O fantasma imaginário de Eleonora é responsável por avivar, com perguntas, a memória de Rosa sobre o dia de seu casamento com Gregório, quando a futura atriz chorava copiosamente, antes da cerimônia, chamando pelo primo Miguel, situação que sua mãe procurava disfarçar ao se referir à festa e ao vestido com metros de cauda de cetim, um verdadeiro casamento de princesa, ocultando as dívidas que assumira para manter as aparências e a dívida maior da filha com o futuro esposo.

É Zelinda, no entanto, a responsável por trazer à tona as revelações mais cáusticas, uma vez que está intimamente ligada a um acontecimento importante para a prima artista. Pelo reflexo do espelho em formato de sol, no centro do biombo art nouveau que ficava em sua sala de jantar, Rosa viu, anos antes, o beijo de Gregório e Zelinda, quando fora buscar pão na cozinha durante o jantar oferecido à prima que acabara de ser nomeada para o cargo de Consultor Jurídico: "Aplausos para a futura grande atriz que representou perfeitamente o papel da esposa traída e distraída. Mais um pouco e já acabo, é dolorido, eu sei, mas é preciso ir até o fundo, você descobriu e continuou igual, tão alegrinha com a cestinha de pão" (Telles, 1999, p. 174). Dessa revelação, surgem outras mais contundentes, como a de que a protagonista sucumbira ao desejo do diretor teatral de "barbicha loura" em troca de seu primeiro grande papel no teatro: Ofélia. É curioso notar que essa lembrança, rememorada antes como algo aparentemente insignificante - supondo inclusive que Rosa não cedera ao desejo do crítico de teatro - só ganha relevo e explicação neste episódio, capítulos depois, quando a protagonista, travestida de Zelinda, esclarece que tal fato acontecera um mês após o famoso jantar, dando início ao jogo de traições, mentiras e desagregação familiar e pessoal da protagonista, embora insistisse na normalidade das aparências.

A atriz compara o afastamento de Zelinda com o voo de um pássaro que se junta aos outros na copa de uma das árvores da praça e na mais velha delas depõe sua cruz: "as testemunhas voltaram aos seus ninhos, a copa aqui da árvore está fervilhante" (Telles, 1999, p. 175). Não é gratuita a presença desses dois grandes símbolos na representação do suposto renascimento e explicitação do conflito de Rosa: árvore e pássaros. A primeira é símbolo da vida e das relações que se estabelecem entre o céu e a terra; ela é o "caminho ascensional ao longo do qual transitam aqueles que passam do visível ao invisível" (Chevalier e Gheerbrant, 2008, p. 85); em perpétua evolução e em ascensão para o céu, simboliza também o aspecto cíclico da evolução cósmica: morte e regeneração (Chevalier e Gheerbrant, 2008, p. 84). Já os pássaros estão associados "à representação da alma que se liberta do corpo ou apenas o símbolo das funções intelectuais", como a inteligência (Chevalier e Gheerbrant, 2008, p. 687). No episódio em questão, os pássaros estão ligados à figura de Zelinda, como a representação imaginária da alma da prima já morta que, depois de trazer à tona o que estava reconditamente guardado em Rosa, volta para a copa de uma árvore, como se regressasse à outra dimensão: já cumpriu seu papel de conectar os dois mundos, terra e céu, consciente e inconsciente da protagonista. É no local de reencontro do passado escondido - a praça com suas árvores e pássaros - que Rosa se sente perdoada, que a conspiração formada por seus mortos se dissipa e permite que ela possa, ao menos por ora, começar a viver a vida que lhe resta, pois já não é possível mais encontrar a praça da infância, nem os amores da adolescência, nem a inocência do primeiro amor. A velha atriz parece despir-se de sua última máscara.

É interessante notar que o perdão a Rosa, vindo simbolicamente da natureza, é sugerido capítulos antes, em uma passagem em que a atriz, entregue aos cuidados de Dionísia enquanto toma uma gemada, motivada pelo cheiro do ovo e do açúcar, volta ao "tempo das gemadas", à adolescência, pelo exercício proustiano da memória do sentimento: "[...] tempo das gemadas. Tempo do Miguel, engulo a colherada de gemada e fico mocinha, quase 
menina. Ele morava na minha rua, era o meu primo rico e lindo, eu estava tão apaixonada. Tão apaixonada mas faz tempo, hem?! Passou" (Telles, 1999, p. 118).

$\mathrm{Na}$ construção textual de Lygia, no entanto, é comum que um fato como aquele, aparentemente sem importância e ainda reforçado por um certo desprezo da personagem "faz tempo, hem?! Passou" -, seja seguido no mesmo parágrafo por outra lembrança marcada pela culpa ou ressentimento que, à primeira vista, não apresenta uma ligação evidente com o que foi recordado anteriormente, como a descrição de um quadro em que o perdão também vem da natureza é capaz de mostrar:

Vi num quadro o tronco de uma árvore se abrir pelo meio e da fenda sair a Deusa do Perdão estendendo os braços para abrigar Caim que fugia como se o chão fosse só serpente e brasa. Não esqueço, o perdão vinha da natureza, só ela aceitava o Caim negro e desgrenhado, mordendo as mãos e mordido, queria parar e não podia. Quero parar e não posso, fujo arrastando os sapatos de ferro, o coração de ferro... Horror, horror. Degenerescência cerebral, querida. Isso de se agarrar ao passado e começar como um rato, roque-roque, roendo as lembranças e se roendo (Telles, 1999, p. 118).

O silêncio que se estabelece entre a recordação do primo e a lembrança do quadro, com a dificuldade de pôr em prática a lição de autoaceitação que este representa, é o elo capaz de revelar sua culpa - depositada em um passado recôndito, digno de vergonha por parte da personagem, relacionado com as figuras de Miguel, o primo amado, e Gregório - e sugerir a resolução iminente de seu conflito. Esse aspecto, nos romances de Telles, de modo geral, ganha corpo na sugestão de renascimento posterior, final, das protagonistas femininas, quando estas decidem interromper a fuga constante ao inimigo e enfrentá-lo. Por essa razão, após sair da Praça da República, Rosa sente que o peso da cruz da memória está deposto em uma árvore e percebe que a multidão passa por ela preocupada com sua própria cruz. Esta última, como "instrumento de suplício e de redenção", congrega, portanto, em uma única imagem, "os dois significados extremos do significado maior que é a Árvore: pela morte para a vida - per crucem ad lucem, pela cruz para a luz" (Chevalier e Gheerbrant, 2008, p. 90), da memória martirizante à memória reconstrutora. Esse estado de leveza e contentamento, oriundos de seu estado renovado, vem expresso na figura do novo táxi que ela chama, o qual a levaria para a casa: o veículo, desta vez, é confortável e o chofer, gentil. Completa o quadro de sua espécie de ressurreição a presença de nuvens brancas, prenúncio de que o sol voltaria a brilhar: agora "não há conspiração" (Telles, 1999, p. 176).

Ao final do romance, Rosa encontra-se internada em uma clínica de desintoxicação e, por meio de uma conversa com Renato Medrado, primo da analista desaparecida, à qual só se tem acesso quando o rapaz trava um diálogo com a empregada da atriz, Dionísia, descobre-se que Rosa deseja voltar aos palcos com Doce pássaro da juventude (Sweet bird of youth), de Tennessee Williams, que tem um significado especial na composição de As horas nuas. A peça apresenta como temas centrais a busca da felicidade, que tem no tempo, na ambição competitiva e na solidão seus maiores inimigos - os quais foram também os dissabores que provocaram o estado depressivo de Rosa. Suas personagens centrais são Alexandra Del Lago, uma atriz de meiaidade, decadente, drogada e alcoólatra, e seu 'gigolô', Chance Wayne, um ator que tentou a sorte em Hollywood mas fracassou e que busca associar sua imagem à da atriz, a fim de abrir, com mais facilidade, os caminhos que podem levá-lo ao sucesso. O rapaz volta a St. Clouds, sua cidade natal, com a atriz, certo de que esta cumprirá seu acordo de indicá-lo para um papel importante. Desse modo, Chance poderá, iludido pelo sonho americano de ser alguém, dizer à mãe, e à sua namorada da adolescência, Heavenly Finley, que venceu e, assim, ter as condições materiais necessárias para levar sua amada para Hollywood: dinheiro, fama, nome. No entanto, ao chegar à cidade, Chance descobre que sua mãe está morta e que sua amada se casará com um médico. A lição que todas as personagens parecem aprender é que o tempo passa e que as ações realizadas na juventude têm consequências no futuro. Alexandra deseja esquecer seu passado como uma das mais belas atrizes hollywoodianas, começando por seu nome - substituído pela expressão Princesa Kosmonópolis -, depois que o peso da idade se transforma em um fardo difícil de carregar na indústria cinematográfica americana, e vê em Chance a chance de se 
agarrar à juventude, o tempo diante de si. Já Heavenly, contaminada com uma doença venérea pelo namorado da adolescência algum tempo antes de sua volta definitiva, devido a complicações, fica estéril. Chance Wayne, no entanto, não consegue o apoio de Alexandra e acaba sendo castrado pelos capangas de Boss Finley, pai de Heavenly e político influente na pequena cidade onde moram, como vingança pelo mal que o gigolô fizera a sua filha.

Apesar do evidente paralelismo entre as personagens de Alexandra e Rosa e, em menor medida, de Chance e Diogo, não se pode esquecer que todas as personagens da peça de Williams recordam sua juventude e, com tristeza, arrependem-se de todas as chances que perderam - o tempo, a beleza, os sonhos - enfim, o paraíso perdido que eles nunca mais conseguirão recuperar. Nesse sentido é que a peça mantém ironicamente o diálogo intertextual com a tragédia pessoal de Rosa, revivida ao longo de todo o romance, até o episódio em que se dá seu renascimento, quando percebe a impossibilidade de capturar o pássaro da juventude, com sua beleza e inocência, levado pelo tempo. Por essa razão, é sintomático que Rosa e Alexandra desempenhem o mesmo papel: o de atriz. No entanto, o fim trágico de Doce pássaro não se repete com Rosa, uma vez que sua suposta metamorfose ao final do romance, provocada pelo enfrentamento de seus inimigos, o sol e o tempo, permitelhe ao menos vislumbrar uma possibilidade de vida com seu antigo gigolô, Diogo. Atuar em Doce pássaro da juventude teria, para a protagonista, então, um duplo sentido: com essa peça, ela não projetaria seus recônditos conflitos nas personagens, mas sim, encenaria, dentro dos limites do texto, sua própria história, enfrentando os medos da velhice, da solidão e do esquecimento do público ao encenar justamente sua tragédia pessoal. Deste modo, seria inteira no palco e na vida, pois faria o movimento contrário ao que realizou durante toda sua carreira como atriz: ao invés de reviver/espelhar dilemas de seu passado nas situações dramáticas encenadas no palco, desta vez, ela levaria sua história pregressa para o teatro, representando a si mesma e, assim, livrar-se-ia dos fantasmas do passado para viver o momento presente em nome de um futuro em aberto - o que fica no plano da suposição.

Assim, pode-se dizer que em As horas nuas prevalece um tipo especial de representação, semelhante à estrutura de caixas chinesas: para encontrar a verdadeira Rosa, na menor e mais recôndita das embalagens, é necessário que se desembrulhe caixa a caixa, começando pelas maiores e mais aparentes, camada a camada, até chegar ao fundo, pois as aparências ocultam sua verdadeira persona. Trata-se, portanto, da representação da representação da protagonista, de uma personagem repleta de personagens, assim como o romance está marcado pelo diálogo com obras da literatura mundial e também de referências a outros textos de Lygia Fagundes Telles; nesse sentido, a ironia fina do gato Rahul é cortante quando afirma não saber onde se encontra a "natureza mais profunda" da atriz, frase normalmente enunciada por ela em entrevistas, que assinala mais uma de suas representações: a Rosa Ambrósio alheia às intrigas e às futilidades, posando de artista solitária. No sentido aqui exposto, se a referência à personagem pela expressão Rosa, Rosae corrobora, em primeira instância, a tentativa da atriz de chegar ao âmago, de buscar algo primordial, reforçada pelo uso do latim, sua declinação é mais um indicativo de que ela pode ter sido várias, revestida de papéis, de acordo com a exigência de cada situação, uma vez que em latim a atividade de declinação de um nome significa enunciar os diferentes modos que ele assume de acordo com as funções que desempenha na oração. Assim, antes de se constituir em "objeto da fala de outras personagens, [...] receptor destas falas ou mero adjunto circunstancial" (Villaça, 1996, p. 136), é como sujeito, portanto, que a atriz pode ter sido uma única Rosa, no singular, mas também mais do que uma, Rosas, no plural.

De modo geral, oscilando seu posicionamento no jogo de exposição e ocultamento, é possível que Rosa se desembrulhe e dispa suas máscaras uma a uma para o leitor, revelando, numa trajetória pessoal, traços de uma trajetória coletiva das mulheres em busca de sua autorrepresentação. $\mathrm{O}$ trabalho de linguagem habilmente articulado tem na intertextualidade, que em nenhum momento é gratuita, um fator primordial, que revela o nível da complexidade da representação que a atriz faz de si própria e dos outros, pois está completamente imbricada no repertório conhecido e/ou encenado de seu mundo profissional, 
o que permite compreender por que, só do palco, não fugira; por que, só como atriz, ela tenha conseguido ser inteira. É a analista de Rosa, Ananta Medrado, quem dá as primeiras pistas sobre o fato de que a atriz misturava seu próprio repertório ao das peças que outrora encenara num caos semelhante ao fundo da sacola em que a atriz carregava objetos de uso pessoal, medicamentos, agenda, chaveiro, mas é Rahul, na posição de espelho verdadeiro de Rosa, quem reflete sobre essa condição: "Impregnou-se tanto dos papéis que representou que facilmente passa de um papel para outro - fragmentos que vai juntando e emendando nas raízes, dependendo da conveniência" (Telles, 1999, p. 103, grifo nosso). Melhor dizendo: quando ela mergulha em seu mundo interior, com sua noção de real, tão caótico quanto a realidade circundante, seu monólogo já vem filtrado por todas as representações que fizera no palco, onde ela realmente foi inteira, uma vez que a atividade como atriz consistia em representação pura, pois encenava uma única personagem a cada vez. Com o uso da intertextualidade, revela-se um importante aspecto da poética da escritora, a saber, a marca deixada por textos e autores consagrados por crítica e público, em seu projeto de criação literária, na medida em que delimita e se insere num amplo espaço cultural hegemonicamente masculino do qual também se apropria para a construção de suas próprias personagens. Unidos às raízes de suas personagens, encontram-se, acionados, fragmentos de outras leituras, de outras personagens, que colaboram com a escritora no processo de construção das próprias personagens, na representação delas que deseja dar. Por essa razão, as peças teatrais mencionadas e suas personagens constituem, respectivamente, espelhos e máscaras no jogo narrativo de As horas nuas.

É justamente nesse aspecto que a escolha das peças anteriormente mencionadas, no tocante à questão das técnicas de representação calcadas no fluxo de consciência, no monólogo e nas operações de lembrança e esquecimento, está ligada especialmente à seleção das personagens femininas que participam do jogo da criação literária de Lygia Fagundes Telles neste romance. Trata-se das representações de figuras femininas que essas personagens encerram, as quais aludem a diversas idades (adolescentes, jovens, maduras e idosas), historicamente localizadas em contextos diferentes, mas que enfrentam a mesma condição de sujeição. Na escolha dos papéis desempenhados por Rosa no teatro, feita pela autora de As horas nuas, figuram modelos de personagens femininas que, embora revelem sentimentos de tempos e lugares distintos, assemelham-se por se constituírem em papéis representativos das várias etapas da tentativa das mulheres de se tornarem sujeito, de terem direito à sua própria história - trajetórias paralelas à vivida por Rosa Ambrósio. Por essa razão, tais personagens percorrem caminhos que partem da submissão e da obediência à figura masculina eencontram na loucura e no suicídio o refúgio ou a punição por ousarem ser, como Ofélia; ou, então, rebelam-se, mostrando a face indomável, por trás da qual se esconde o medo de ser ou a incapacidade de ser sem a presença de um marido ou pai, como Amanda; ou conseguem dar visibilidade aos desejos recônditos a partir de pequenas desobediências, apenas no plano da memória ou da alucinação, como Alaíde; ou, ainda, o sofrimento da mulher, outrora uma celebridade, descida do pedestal com a chegada da velhice, como Alexandra Del Lago. Desse modo, a escritora opera com representações tradicionais da figura feminina, como a velha dicotomia anjo $\mathrm{x}$ demônio, mas delas faz uso próprio ao utilizar-se de alguns aspectos cruciais deixados na memória por essas representações para retratar, em sua protagonista e nos personagens com quem Rosa contracena, as transformações do papel social das mulheres.

Lygia, ao se utilizar do diálogo intertextual com o teatro, descortina, a partir de personagens femininas marcantes escritas por famosos dramaturgos, a encenação de uma possível história da sujeição da mulher pelo patriarcado e de suas tentativas de rompimento com essa estrutura repressora: os entraves à sua emancipação, o que houve quando a figura feminina abandonou o espaço privado da casa em favor do espaço público, e como seu olhar retrospectivo permite verificar os erros e acertos da permanência em um ou outro espaço, na difícil arte de harmonizar a convivência em ambos. 


\section{Referências}

CANDIDO, Antonio (2007). A personagem do romance. In: CANDIDO, Antonio et al. A personagem de ficção. 11. ed. São Paulo: Perspectiva.

AUERBACH, Erich (1994). A meia marrom. In: AUERBACH, Erich. Mimesis: a representação da realidade na literatura ocidental. 3. ed. São Paulo: Perspectiva.

BRADLEY, A. C. (2009). A tragédia shakesperiana: Hamlet, Otelo, Rei Lear, Macbeth. Tradução de Marcelo Brandão Cipolla. São Paulo: Editora WMF Martins Fontes.

CHEVALIER, Jean; GHEERBRANT, Alain (2008). Dicionário de símbolos: mitos, sonhos, costumes, gestos, formas, figuras, cores, números. Tradução de Vera da Costa e Silva et al. 22. ed. Rio de Janeiro: José Olympio.

DALCASTAGNÈ, Regina (2003). Sombras da cidade: o espaço na narrativa brasileira contemporânea. Estudos de literatura brasileira contemporânea, Brasília, n. 21, p. 33-53, jan./jun.

FRYE, Northrop (1973). Anatomia da crítica. Tradução de Péricles Eugênio da Silva Ramos. São Paulo: Cultrix.

GOMES, Renato C. (1999). A cidade, a literatura e os estudos culturais: do tema ao problema. Ipotesi: Revista de estudos literários, Juiz de Fora, v. 3, n. 2, p. 19-30. Disponível em: https://bit.ly/2rFk0fJ. Acesso em: 8 mai. 2006.

LUCENA, Suênio Campos de (2008). Esquecimento e lembrança em Lygia Fagundes Telles. Tese (Doutorado em Teoria Literária e Literatura Comparada) - Universidade de São Paulo, São Paulo.

MAGALDI, Sábato (1998). Nelson Rodrigues: a peça que a vida prega. In: MAGALDI, Sábato. Moderna dramaturgia brasileira. São Paulo: Perspectiva.

MAGALDI, Sábato (1999). Tennessee Williams evoca o passado. In: MAGALDI, Sábato. O texto no teatro. 2. ed. São Paulo: Perspectiva.

NOVAIS, Fernando A.; MELLO, João M. Cardoso de (1998). Capitalismo tardio e sociabilidade moderna. In: SCHWARCZ, Lilia M. (Org.). História da vida privada no Brasil: contrastes da intimidade contemporânea. São Paulo: Companhia das Letras. v. 4.

NUNES, Luiz Arthur (2004). Apresentação. In: RODRIGUES, Nelson. Teatro completo- Peças psicológicas, v. 1, 2. ed. São Paulo: Nova Fronteira.

ORTIZ, Renato (1999). A moderna tradição brasileira. São Paulo: Brasiliense.

PEDRA, Mabel Knust (2005). O círculo de giz: a família burguesa patriarcal em Lygia Fagundes Telles. Dissertação (Mestrado em Letras) - Universidade Federal Fluminense, Niterói.

ROSENFELD, Anatol (1993). A essência do teatro. In: ROSENFELD, Anatol. Prismas do teatro. São Paulo: Perspectiva. p. 21-26.

ROSENFELD, Anatol (1996). Reflexões sobre o romance moderno. In: ROSENFELD, Anatol. Texto/Contexto I. São Paulo: Perspectiva.

SILVA, Lilian Cristina Brandi da (2003). Do romance de formação à deformação do romance: O silêncio, Os teclados e As horas nuas. Tese (Doutorado em Letras). Instituto de Biociências, Letras e Ciências Exatas, Campus de São José do Rio Preto, Universidade Estadual Paulista.

TELLES, Lygia Fagundes (1999). As horas nuas. Rio de Janeiro: Rocco.

VILLAÇA, Nízia (1996). Paradoxos do pós-moderno: sujeito \& ficção. Rio de Janeiro: Editora da UFRJ. 